\title{
GLOBALIZATION AND MAIN TRENDS OF GLOBAL ECONOMIC PERFORMANCE: TRADE AND INVESTMENTS
}

\author{
EMIR ETERIA \\ Doctor of Economics, Associate Professor, \\ Caucasus University, Georgia \\ eeteria@cu.edu.ge
}

KEYWORDS: GLOBALIZATION, NATION STATE; DEVELOPING AND TRANSITION ECONOMIES, TRADE, INVESTMENTS.

For citation: Eteria, E. (2019). Globalization and Main Trends of Global Economic Performance: Trade and Investments, Globalization And Business, №8, pp. 90-95. https://doi.org/10.35945/gb.2019.08.010

\section{INTRODUCTION}

Globalization is multidimensional, multipart and multispeed phenomena affecting all countries and nations in the world. Therefore, since the 1990s, the benefits and challenges of economic globalization and transformation of the Nation States' role as well as effects of economic globalization on developing and transition countries has become one of the most debated issues in academic, political and business circles.

Noteworthy, that there are many conflicting approaches towards globalization. These approaches could be described as neoliberal, rejectionist, reformist and transformist views on globalization (Sholte, 2005: 37-38). However, it should be noted that the leading form of globalization still is neoliberal globalization, while other perspectives are opposing ideas to neoliberal globalization. Therefore, in modern debates about globalization there are two most challenging issues: first, effects of neoliberal economic globalization on the Nation State and second, interaction of neoliberal economic globalization and economic performance of developing and transition economies.

The article is focused on major aspects of neoliberal economic globalization and its impact on the Nation State and namely, on developing and transition countries. In the next section, peculiarities of neoliberal economic globalization as well as effects of economic globalization on Nation State are discussed. In the following part of the article, in the light of neoliberal economic globalization, data of the United Nations Conference on Trade and Development (UNCTAD) on trade and investment performance of developing and transition economies is analyzed and the final stage, conclusions are drawn.

\section{GLOBALIZATION AND NATION STATE: SOME THEORETICAL ASPECTS}

Since 1990s, different aspects of globalization have been widely discussed and analyzed by social scientists (Hirst and
Thompson, 1999; Stiglitz, 2002, 2007; Bhagwati, 2004; Wolf, 2005; Sholte, 2005; Friedman, 2007; Rodrik, 2011; Eteria, 2006, 2009; Putkaradze, 2007; Bedianashvili, 2016; Mekvabishvili, 2016, 2018; etc). It is clear, that globalization has many dimensions, such as economic, political, cultural, social, etc. However, among these types of globalization, economic dimension could be considered as foundation as well as determinant of development of other forms of globalization, including political and social globalization. Moreover, economic globalization is more advanced type of globalization and as Stiglitz (2007) noted, "economic globalization has been outpacing political globalization" (p. 291). Noteworthy, that economic globalization includes all nation states with different degrees of integration into global economy. Globalization as a process leads to global economy, which according to Castels (2000) "...is an economy with the capacity to work as a unit in real time on planetary scale" (p. 259). However, as Hirst and Thompson (1999) argued, the modern world economy is internationalized, not globalized. It is clear, that internationalization of economic relations among countries is a foundation of development of economic globalization processes. Gradual liberalization of international economic relations starting after the World War II underlines a primary importance of the economic dimension of globalization.

Noteworthy, that modern form of economic globalization is based on concept of neoliberalism. A fundamental idea of neoliberal economic globalization is so-called "small government" and openness for trade and investment, which has been considered as a necessary precondition for economic development of any nation in the world since 1980 s. A neoliberal approach towards economic globalization was embodied in International Monetary Fund (IMF) and World Bank recommendations, which is known as "Washington Consensus", elaborated in the 1980s. As Rodrik (2011) noted "Free market economics was in the ascendancy, producing what has been variously called the Washington Consensus, market fundamentalism, or neoliberalism" (p. 77). Moreover, 
for many, globalization was perceived as Americanization or Westernization and as Stiglitz (2007) noted, "If globalization is being used to advance the American model of a market economy, many elsewhere are not sure they want it" (p. 10). However, neoliberal reforms implemented in the USA and the Great Britain in the 1980s was extended towards many developing and transition countries primarily by the International Monetary Fund. Consequently, "1990s were years of intensification of neoliberal economic globalization and therefore, widespread beliefs in superiority of market economy over government intervention in economy and government regulation in general" (Eteria, 2019: 87). Hence, neoliberal globalization has been oriented to achieve fast formation of a globalized economy based on market mechanisms rather than government intervention and regulations.

A neoliberal globalization has become triumphant and the only form of globalization, which despite critics and setbacks continues to be a leading policy and ideology. Noteworthy, that major opponents of globalization criticize neoliberal form of globalization, not globalization itself, which is considered as inevitable process of economic development. Therefore, economic globalization for many countries in the world, especially for developing countries and countries with transition economy was the process of adjustment to changing conditions of world economic development caused by the necessity of economic openness on the one hand, and by the policy of major developed countries as well as by international organizations on the other hand. Obviously, economic autarchy was more harmful policy choice than economic openness, and therefore, the establishment of an open, less regulated economy was in line with the goals of these countries.

Neoliberal economic globalization, using a unified approach to the countries without consideration of differences in level and needs of development, has enhanced controversial attitude towards economic globalization in general. Therefore, the neoliberal globalization was blamed of diminishing of the role of national governments to regulate economy. As a result, economic globalization in its neoliberal form increased the contradictory relationship between the market and government in favor of the market. It is clear, that the policy of major developed countries and international organizations emerged as the main cause of government role transformation. Accordingly, the economic factor was main reason of transformation often associated with weakening of government's role in regulation of economy, especially in the developing and transition countries.

It is clear, that controversy towards neoliberal globalization, especially in developing and transition countries was based on belief that it has been shrinking political maneuver room for governments to implement reforms necessary to raise welfare of citizens. Therefore, as Grindde (2000) noted, "policymakers in poor countries have reason to worry that, despite their best effort, globalization will constrict rather than expand the capacity to develop" (p. 179). As a result, most problematic issue related to economic globalization is the interaction of government intervention and market mechanisms, because "economic success requires getting the balance right between the government and the market" (Sti- glitz, 2007: XV ). However, as economic history demonstrates finding right balance between market and government is the most complicated issue in economics and it depends on economic as well as non-economic factors of development. Moreover, it should be noted that "give too much power to governments, and you have protectionism and autarchy. Give markets too much freedom, and you have unstable world economy with little social and political support from those it is supposed to help" (Rodrik, 2011: XVI). Therefore, neoliberal globalization has been a policy to achieve a fast globalization, which caused many problems in international economic relations.

Noteworthy, that more deep integration into globalizing world economy through trade and investment is one of the most important factors to improve the level of economic development in transition and developing countries. As Frenkel (2000) pointed out "International trade and investment can be a powerful source of growth in poor countries, helping them catch up with those who are ahead in endowments of capital and technology" (p. 62). However, "Most countries did welcome multinational enterprises and long-term foreign investors, but short term lending and borrowing or portfolio flows (so-called "hot money") were viewed differently, as a source of financial instability rather than economic growth" (Rodrik, 2011: 90). Therefore, as Gritch (2005) argues, "Contrary to neo-liberal claims that global economic integration promotes less developed nations' greater economic prosperity, the opposite may be the case" (p. 13). Consequently, in addition to claims on negative effects on Nation State, for "skeptics" neoliberal economic globalization is also associated with deepening the gap between developed and developing world, so-called "North-South" divide.

It is clear, that economic globalization transformed government economic policy in transition and developing countries rather than in developed countries and "with this increased integration, developing countries become more vulnerable to fluctuations in international capital flows and trade" (Grindde, 2000: 183). Thus, capital movement is the main reason of government role transformation. Transnational companies significantly influence the policy of recipient countries and they often are obliged to adapt to the requirements of transnational companies. As a result, "For many people, multinational corporations have come to symbolize what is wrong with globalization. Many could say they are primary cause of its problems" (Stiglitz, 2007: 187), because "The international mobility of firms and of capital also restricts a nation's ability to choose the tax structure that best reflects its needs and preferences" (Rodrik, 2011: 193). Consequently, economic globalization pushes governments to adapt to the changing needs of international capital, but it simultaneously does not mean that governments cannot transform their policies in favor of more autonomous economic policy.

It is obvious, that economic globalization intensifies cooperation as well as competition on regional and global level and therefore, enhances economic and political interdependence among countries. However, this could be considered as a government policy transformation to achieve national economic goals through intensification of cooperation at the re- 
gional and global level. As a result, "Political interdependence does not mean that states trade their objectives, but that they advance them through power sharing" (Weiss, 1999: $70)$, and "Globalization does not undermine the state but includes the transformation of the state forms: it is both predicated on and produces such transformations" (Shaw, 1997: 498). Economic globalization undermines the governments' role in its traditional sense to determine economic goals of development neglecting international economic conditions, but at the same time, gives to government other instruments to support development. Hence, "Globalization is strongly affecting governance, but it is far from making nation state obsolete as some prophets claim" (Nye and Donahue, 2000: 36). In addition, as Wolfensohn stated, "Without an effective state, sustainable development, both economic and social, is impossible" (World Bank: III). Accordingly, developing and transition countries in order to actively participate in international trade as well as to attract Foreign Direct Investments (FDI) should make their investment climate more attractive, which frequently requires transformation of government policy in many areas of economic activity. As a result, despite intensification of the globalization processes, even in the form of neoliberal globalization, the Nation State remains as the most important actor in the world economy.

\section{MAJOR PECULIARITIES OF GLOBAL TRADE AND INVESTMENT}

Noteworthy, that Major negative aspects of neoliberal globalization, underlined by "skeptics" are negative effects of neoliberal globalization on developing and transition economies. Neoliberal economic globalization was blamed by its negative effect on trade and investment performance of above-mentioned countries. However, as UNCTAD data demonstrates in 1990 exports growth rate of developing countries and developed countries was the same $(13,3 \%)$, while in 2018 growth rate of developing countries exports was higher than exports growth rate of developed countries (10,4\% and $8,5 \%$ respectively). Regarding transition economies, exports growth rate in 1990 was $-3,2 \%$, while in 2018 was $23,1 \%$. A considerable decrease of transition countries exports growth rate was observed in 1991 (-49,0\%), due to disintegration after collapse of the Soviet Union and block of socialist countries in general. In addition, significant decline in the world export was observed in 2009 because of the global financial crisis, when exports from developing countries decreased by $20,5 \%$, from transition economies by $35,5 \%$ and from developed countries by $22,3 \%$. Generally, during $1990-$ 2018 , exports annual average growth rates of developing and transition countries were $9,5 \%$ and $8,8 \%$ respectively, while exports annual average growth rate of developed countries was $5,7 \%$ (Figure 1).

Noteworthy, that countries involvement in globalization depends not only on exports but also on imports. As the statistical data indicate in 1990 imports growth rate of developing countries was $9,2 \%$, which was smaller than imports growth rate of developed countries (13,5\%). In contrast, in
Figure 1. Exports average growth rates by country groups in 1990-2018

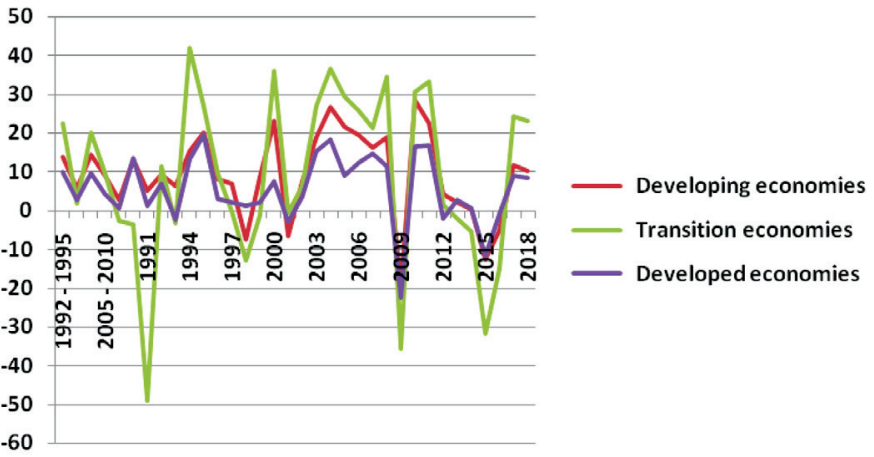

Source: Elaborated by the author based on data from UNCTAD statistics; https://unctadstat.unctad.org

2018 imports growth rate of developing countries was higher than imports growth rate of developed countries (10,9\% and 9,5\% respectively). Regarding transition economies, imports growth rate in 1990 was $8,0 \%$, while in 2018 was 9,2\%. A sharp decline of imports in transition countries was observed in 1991(-58,1\%) and in 2009 (-33,0\%). Moreover, in 2009, due to global financial crisis, imports in developing countries as well as in developed countries drastically declined $(-19,1 \%$ and $-24,4 \%$ respectively). In general, during 1990-2018, imports annual average growth rates of developing and transition countries were $9,3 \%$ and $7,7 \%$ respectively, while imports average growth rate of developed countries was 5,9\% (Figure 2).

Figure 2. Imports average growth rates by country groups in 1990-2018

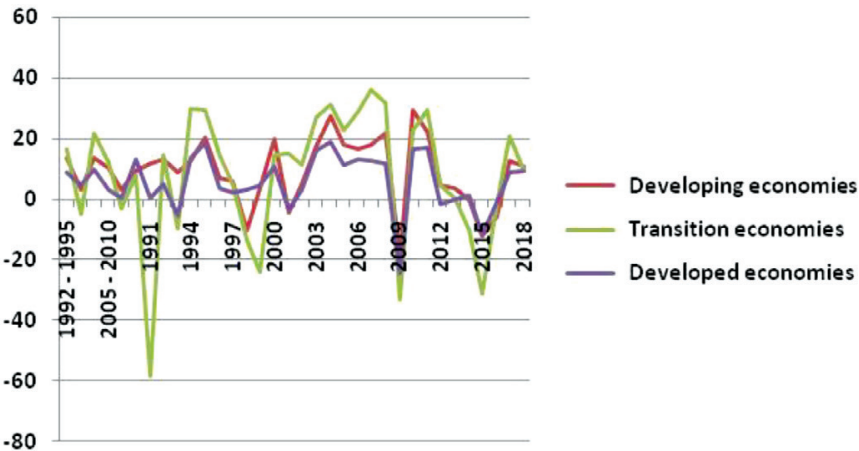

Source: Elaborated by the author based on data from UNCTAD statistics; https://unctadstat.unctad.org

It is clear, that besides trade Foreign Direct Investment is the major indicator to evaluate countries/country groups' involvement in globalization. Moreover, it is widely accepted that Foreign Direct Investments play key role in the economic development of developing and transition countries. Noteworthy, that in 1990, developing countries share in world Foreign Direct Investments (inward) was 16,9\%, transition economies share was $0,03 \%$, while developed countries share was $83 \%$. This picture drastically changed and in 2014 as well as in 2018, developing countries share in world Foreign Direct Investments was higher than developed countries share. In 2014 developing countries share was 49,9\% and developed 
countries share was $45,9 \%$. In 2018, this difference increased and developing countries share was $54,4 \%$, while developed countries' share was $42,9 \%$. Notable, that between 1990 and 2000 average share of developing countries' in world Foreign Direct Investments (inward) was 29, 3\%, in 2001-2010 was $34,4 \%$, while in 2011-2018 average share was $44,2 \%$. Therefore, increasing trend of developing countries share in world FDls is obvious. In 1990-2018, transition economies share in world Foreign Direct Investments was not significant (1\% in 1992 and 2,6\% in 2018). In 2008, share of transition economies reached the highest level and amounted 7, 9\% of world FDIs (Figure 3).

Figure 3. Foreign Direct Investment: inward (\% of total world) by country groups in 1990-2018

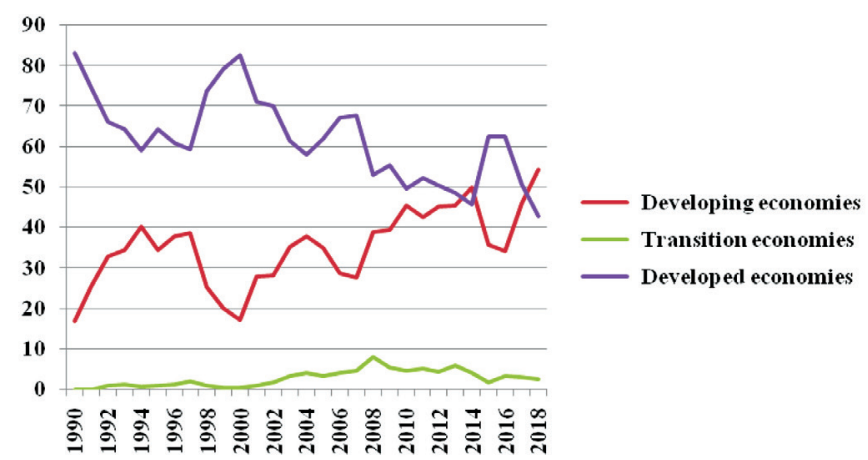

Source: Elaborated by the author based on data from UNCTAD statistics; https://unctadstat.unctad.org

It is clear, that countries/country groups' involvement in the international capital movement and in globalization processes in general, depends not only on inward Foreign Direct Investments, but also on outward FDIs. Noteworthy, that in 1990 share of developing countries in outward Foreign Direct Investments was 5,3\%, while in 2018 this share was significantly higher (41,1\%). A share of developed countries in outward Foreign Direct Investments in 1990 and 2018 was $94,6 \%$ and $55 \%$ respectively. It should be noted that developing countries share in outward FDIs has increasing trend. Notable, that between 1990-2000 average share of developing countries' in outward FDIs was 10,4\%, in 2001-2010 was $14,1 \%$, while in 2011-2018 average share of developing countries in outward world FDIs significantly increased and reached $30,1 \%$. Transition economies share in outward world FDls was not significant $(0,1 \%$ in 1998 and 3,7\% in 2018). A maximum level of transition economies share in outward FDls was observed in 2013-2014 (5, 50\% and 5, 56\% respectively) (Figure 4).

Conducted analysis of the trade and investments performance during 1990-2018 demonstrates developing and transition countries' increased participation in trade and FDIs
Figure 4. Foreign Direct Investment: outward (\% of total world) by country groups in 1990-2018

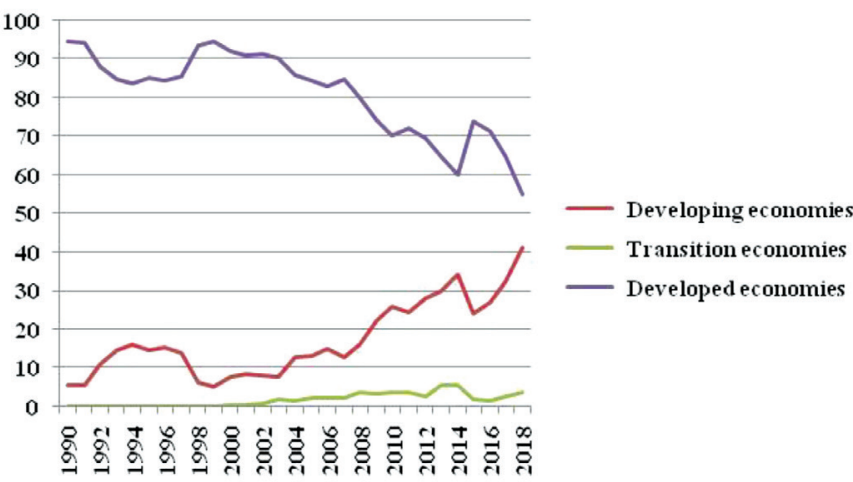

Source: Elaborated by the author based on data from UNCTAD statistics; https://unctadstat.unctad.org

movement and therefore, their rising involvement in globalizing economy. The data also underlines an intensification of trade relations of transition and developing countries as well as their increased openness for Foreign Direct Investments and rising share in outward world FDIs. As a result, despite some slowdown of globalization due to global financial crisis in 2007-2008, trade and investment openness remains as major tendency of global economic performance and therefore, opinions on de-globalization of world economy is rather exaggerated.

\section{CONCLUSION}

Despite neoliberal economic globalization, Nation State remains as a key actor in the world economy. It is clear, that economic globalization frequently pushes governments to choose between capital inflow, which is a necessary precondition for economic growth, and more economic autonomy, which might be more preferential, especially in the short-run. Neoliberal economic globalization to some extent shrinks governments' ability to regulate the economy, but at the same time, gives to government more possibilities to facilitate economic development by attracting foreign capital. Therefore, economic globalization does not reduce the key role of government in regulation of domestic and foreign economic relations. During 1990-2018, developing and transition countries participation in globalizing world economy significantly increased via increased trade relations and growing involvement in movement of Foreign Direct Investments. Consequently, despite some setbacks, economic globalization remains as the leading characteristic of the world economic development and process of de-globalization is not evident. 


\section{REFERENCES:}

1. Bedianashvili, G. (2016). The Global Business Environment, European Integration and the Cultural Potential of Social-economic Development of Georgia. Journal "Globalization and Business". №1, pp. 19-25 (in Georgian).

2. Bhagwati, J. (2004). In Defense of Globalization, Oxford University Press.

3. Castels, M. (2000). Global Economy, in The Global Transformations reader : an introduction to the globalization debate. Held, D. and McGrew, A. G. (eds), Cambridge: Polity.

4. Eteria, E. (2006). A Comparative Analysis of Modern Concepts of Globalization. Journal “Ekonomika”, \#11-12, pp. 110-116, (in Georgian).

5. Eteria, E. (2009). Globalization and National Economy: Theory and Policy. Tbilisi, "Universali”, (in Georgian).

6. Eteria, E. (2019). Economic Globalization and Regional Trade Agreements: Recent Developments, Ekonomisti, Vol. XV, №1, pp. 86-93.

7. Frenkel, J. (2000). Globalization of the Economy. In Governance in a globalizing world. Nye, J. S. and Donahue, J. D. (eds.), Brookings Institution Press.

8. Friedman, T. L. (2007). The World is Flat: a Brief History of the Twenty-first Century. Picador.

9. Grinddle, M. S. (2000). Ready or Not: The Developing World and Globalization. In Governance in a globalizing world. Nye, J. S. and Donahue, J. D. (eds.), Brookings Institution Press.

10. Gritch, M. "The Nation-State and Economic Globalization: Soft Geo-Politics and Increased State Autonomy?" Review of International Political Economy, Vol. 12, No. 1, Aspects of Globalization (Feb., 2005), pp. 1-25

11. Hirst, P., Thompson, G. (1999). Globalization in Question: the International Economy and the Possibilities of Governance. Cambridge: Polity Press; Malden, MA: Blackwell Publishers.

12. Mekvabishvili, E. (2016). Unity of Globalization and Modernization - The Modern Economic Development Paradigm, Journal "Globalization and Business", №2, pp. 30-36 (in Georgian);

13. Mekvabishvili, E. (2018). The Financial Crisis of the Globalization Era and the Economy of Georgia. Tbilisi, "Inteleqti" (in Georgian)

14. Nye, J. S. and Donahue, J. D. (eds.), (2000). Governance in a Globalizing World. Brookings Institution Press.

15. Putkaradze, R. (2007). Directions of International Trade Development under Globalization. Journal "Georgian Economy", №5, pp. 67-71 (in Georgian).

16. Rodrik, D. (2011). The Globalization Paradox : Democracy and the Future of the World Economy. New York; London: W. W. Norton \& Co.

17. Stiglitz, J. E. (2002). Globalization and its Discontents. New York: W. W. Norton \& Co.

18. Stiglitz, J. E. (2007). Making Globalization Work. New York: W. W. Norton \& Co.

19. Shaw M. "The State of Globalization: Towards a Theory of State Transformation." (Autumn, 1997), Review of International Political Economy, Vol. 4, No. 3, The Direction of Contemporary Capitalism pp. 497-513

20. Scholte, J. A. (2005). Globalization: A Critical Introduction. Palgrave Macmillan;

21. The International Bank for Reconstruction and Development/the World Bank. (1997). World Development Report: The State in a Changing World. Oxford University Press.

22. Weiss, L. (1999). "Globalization and National Governance: Antinomy or Interdependence?" Review of International Studies, Special Issue, 25 (5), December, pp. 59-88

23. Wolf, M. (2005). Why Globalization Works. Yale University Press; 2nd edition.

24. UNCTAD statistics; https://unctadstat.unctad.org 


\title{
GLOBALIZATION AND MAIN TRENDS OF GLOBAL ECONOMIC PERFORMANCE: TRADE AND INVESTMENTS
}

\author{
EMIR ETERIA \\ Doctor of Economics, Associate Professor, \\ Caucasus University, Georgia \\ eeteria@cu.edu.ge
}

KEYWORDS: GLOBALIZATION, NATION STATE; DEVELOPING AND TRANSITION ECONOMIES, TRADE, INVESTMENTS.

For citation: Eteria, E. (2019). Globalization and Main Trends of Global Economic Performance: Trade and Investments, Globalization And Business, №8, pp. 90-95. https://doi.org/10.35945/gb.2019.08.010

\section{SUMMARY}

Globalization and its impact on developing and transition economies are among most debated issues in social sciences. Globalization is multidimensional, multipart and multispeed phenomena affecting all countries and nations in the world. However, economic dimension of globalization could be considered as foundation as well as determinant of development of other forms of globalization, including political and social globalization. It is obvious, that economic globalization intensifies cooperation as well as competition on regional and global level and therefore, enhances economic and political interdependence among countries.

There are many conflicting approaches towards globalization. However, a leading form of globalization still is neoliberal globalization, while other perspectives are opposing ideas to neoliberal globalization. A fundamental idea of neoliberal economic globalization is so-called "small government" and openness for trade and investment, which has been considered as a necessary precondition for economic development of any nation in the world since 1980s. Noteworthy, that major negative aspects of neoliberal globalization, underlined by "skeptics" are negative effects of neoliberal globalization on trade and investment performance of developing and transition economies.

Conducted analysis of trade and investment performance of developing and transition economies demonstrates their growing involvement in globalizing world economy. According to data of the United Nations Conference on Trade and Development (UNCTAD), during 1990-2018, exports annual average growth rates of developing and transition countries were $9,5 \%$ and $8,8 \%$ respectively, while exports annual average growth rate of developed countries was 5, 7\%. Moreover, in 1990-2018, imports annual average growth rates of developing and transition countries were $9,3 \%$ and $7,7 \%$ respectively, while imports average growth rate of developed countries was $5,9 \%$. It is clear, that besides trade, Foreign Direct Investment is the major indicator to evaluate countries/ country groups' involvement in globalization. Noteworthy, that between 1990 and 2000 average share of developing countries in world Foreign Direct Investments (inward) was $29,3 \%$, in $2001-2010$ was $34,4 \%$, while in $2011-2018$ average share was $44,2 \%$. In 2018, developing countries share in inward world Foreign Direct Investments was 54, 4\%, while developed countries share was $42,9 \%$. It is clear, that countries/country groups' involvement in the international capital movement and in globalization processes in general, depends not only on inward Foreign Direct Investments, but also on outward FDIs. In 1990-2000, average share of developing countries in outward FDIs was $10,4 \%$, in 2001-2010 was 14 , $1 \%$, while in 2011-2018 average share of developing countries in outward world FDIs significantly increased and reached $30,1 \%$. The data underlines an intensification of trade relations of transition and developing countries as well as their increased openness for Foreign Direct Investments and rising share in outward world FDIs.

As a result, during 1990-2018, developing and transition countries' involvement in globalizing world economy significantly increased via increased trade relations and growing participation in movement of Foreign Direct Investments. Consequently, despite some setbacks, economic globalization remains as the leading characteristic of the world economic development and process of de-globalization is not evident. 